\title{
Novel Sources of Resistance to Fusarium Stalk Rot of Maize in Tropical Africa
}

\author{
C. G. Afolabi, International Institute of Tropical Agriculture (IITA), Ibadan, Nigeria and Department of Crop Protec- \\ tion and Environmental Biology, University of Ibadan, Nigeria; P. S. Ojiambo, Department of Plant Pathology, \\ North Carolina State University, Raleigh 27695; E. J. A. Ekpo, Department of Crop Protection and Environmental \\ Biology, University of Ibadan, Nigeria; and A. Menkir and R. Bandyopadhyay, IITA, Ibadan, Nigeria
}

\begin{abstract}
Afolabi, C. G., Ojiambo, P. S., Ekpo, E. J. A., Menkir, A., and Bandyopadhyay, R. 2008. Novel sources of resistance to Fusarium stalk rot of maize in tropical Africa. Plant Dis. 92:772-780.

Fusarium stalk rot is one of the most widespread and destructive diseases of maize, and deployment of resistant genotypes is one of the most effective strategies for controlling the disease. Fifty inbred lines and four checks from the breeding program of the International Institute of Tropical Agriculture were evaluated in field trials at Ikenne and Ibadan, Nigeria in 2003 and 2004 to identify new sources of resistance to stalk rot caused by Fusarium verticillioides. Evaluations were conducted under artificial inoculation and natural infection at Ibadan and Ikenne, respectively. Disease severity was recorded using a severity scale (SS) and direct estimation of stalk discoloration (SD). The two methods of disease assessment were compared and combined to classify genotypes into resistance groups using results from rank-sum analysis. In 2003, disease severity ranged from SS $=1$ to 5 and $S D=1.3$ to $33.8 \%$ at both locations. Both SS and SD were significantly $(P<0.01)$ higher in 2003 than in 2004 at the two locations. In both years, inbred lines significantly differed in SS $(P<0.02)$ and SD $(P<0.04)$ at Ibadan. Similarly, inbred lines significantly differed in SS $(P<0.04)$ and SD $(P<0.04)$ when genotypes were evaluated at Ikenne. Disease assessments based on SS and SD were significantly correlated (0.68 $<r<0.95, P<0.01)$ in both years. Based on the results from rank-sum analysis, inbred lines were separated into highly resistant, resistant, moderately resistant, moderately susceptible, susceptible, and highly susceptible groups. At Ibadan, $6(11.1 \%)$ and $8(14.8 \%)$ were identified as highly resistant and resistant, respectively, whereas 11 (20.4\%) were identified as resistant at Ikenne. Inbred lines 02C14609, 02C14643, 02C14654, and 02C14678 were consistently classified as either highly resistant or resistant to stalk rot across locations and years while the check genotypes were classified either as susceptible or moderately susceptible to stalk rot. These four inbred lines identified to have high levels of disease resistance may be used for breeding maize with resistance to Fusarium stalk rot.
\end{abstract}

Fusarium stalk rot is one of the most common and destructive diseases of maize worldwide. The disease is caused by a complex of several fungal pathogens and secondary colonizers $(14,35)$. In the United States, Fusarium verticillioides (Sacc.) Nirenberg, F. proliferatum (Matsush.) Nirenberg ex Gerlach \& Nirenberg, and F. subglutinans (Wollenw. \& Reinking) P.E. Nelson, Toussoun \& Marasas are the predominant members of the stalk rot complex (21). In Nigeria, F. moniliforme had been implicated earlier as the major stalk rot pathogen (2). However, recent studies have shown that $F$. verticillioides is the most important stalk rot pathogen (34) as well as the predominant member of the Fusarium ear rot complex $(1,4)$ infecting maize in Nigeria.

Corresponding author: R. Bandyopadhyay

E-mail: r.bandyopadhyay@cgiar.org

Accepted for publication 20 January 2008.

doi:10.1094/PDIS-92-5-0772

(C) 2008 The American Phytopathological Society
Members of the Fusarium stalk rot complex invade the maize plant through natural entry points such as nodes, through wounds created by insects or mechanical damage, by direct penetration of the roots and stalk tissue $(13,20)$, or through infected seed (36). The disease generally is characterized by disintegration of the pith tissue at or near the base of the stalk and is associated with senescence of stalk pith cells. Severe stalk rot results in yield loss through premature plant death or lodging. In addition, lodging of infected stalks makes harvesting difficult. In the tropics, about $40 \%$ of the fields are infested with Fusarium stalk rot with a severity level of about $10 \%$ (2). Stress conditions such as drought, excess water, lack of sunlight, leaf diseases, and insect damage, which reduce photosynthesis and the production of sugars, can predispose maize plants to severe stalk rot (8).

Disease management options that reduce Fusarium stalk rot ensure high grain yield, minimize harvest losses, and improve stalk quality for livestock feed. In sub-Saharan Africa, the livestock industry is expanding and, with population expansion on a fixed area of land, agriculture is being driven toward greater intensification. The major constraint to livestock production is availability of animal feed, particularly during the dry season (23). As more of the existing rangeland is converted into cropland, crop residues, such as maize stalks, will become the dominant feed resource in moist savanna ecological zones $(30,33)$. Thus, there is need to have good quality maize stalks that can serve as livestock feed. Among the management options that have been proposed, use of resistant maize cultivars is considered to be an effective strategy in minimizing the damage from Fusarium stalk rot (27).

Several studies $(17,18,31)$ have recommended artificial inoculation during evaluation of breeding materials, whereas other studies $(20,22)$ have recommended natural infection because artificial infection may not result in typical disease symptoms. The International Institute of Tropical Agriculture (IITA) has developed maize inbred lines that are adapted to the West African agro-ecological zones. These inbred lines generally are developed under high disease pressure and possess higher levels of resistance to mycotoxin accumulation such as aflatoxin $(6,25)$ than maize germplasm found elsewhere. Maize inbred lines from IITA have been evaluated for Fusarium ear and fumonisin resistance (1) but their level of resistance to Fusarium stalk rot has not been determined. Therefore, the objectives of this study were to (i) evaluate IITA maize inbred lines for resistance to Fusarium stalk rot under artificial and natural infection, (ii) compare disease assessments based on a severity rating scale with assessments based on direct estimation of stalk discoloration, and (iii) identify novel sources of resistance to Fusarium stalk rot. Inbred lines possessing resistance to Fusarium stalk rot would be valuable breeding stock for use as parents of hybrids and synthetics that can be grown by farmers.

\section{MATERIALS AND METHODS}

Planting material and field sites. Fiftyfour maize inbred lines, three hybrids, and an open-pollinated cultivar from the maize breeding program at IITA were planted to evaluate their resistance to Fusarium stalk rot caused by $F$. verticillioides in two agroecological zones in Nigeria. The study was conducted in 2003 and 2004 during the rainy season at the IITA field sites in 
Ikenne and Ibadan. The field site at Ibadan is located in the derived savanna region, $7^{\circ} 30^{\prime} \mathrm{N}$ latitude and $3^{\circ} 54^{\prime} \mathrm{E}$ longitude, where soils are typically ferric luvisols (26). The Ikenne site is located in the rain forest belt, $6^{\circ} 52^{\prime} \mathrm{N}$ latitude and $3^{\circ} 43^{\prime} \mathrm{E}$ longitude, where soils are typically entric nitosols. At Ibadan, where weather conditions are highly variable, inbred lines were evaluated under artificial infection to ensure adequate and consistent disease pressure while field plots at Ikenne were used to evaluate inbred lines for stalk rot resistance under natural infection. The three hybrids (9031-29, Oba super 1, and Oba super 2) and an open-pollinated cultivar (AK9443DMRSR), which have been released in Nigeria as commercial cultivars, served as checks in both trials.

In 2003, fields were planted manually ( 2 seeds per hill) on 19 June at Ibadan and 6 June at Ikenne, in a single-row plot $5 \mathrm{~m}$ long, spaced $0.75 \mathrm{~m}$ between rows, $0.25 \mathrm{~m}$ between plants within rows, and 21 plants per row in an augmented (unreplicated) experimental design (24). Plants were thinned to one plant per hill 2 weeks after planting and a compound fertilizer (NPK) was applied at the rate of $60 \mathrm{~kg} / \mathrm{ha}$. Additional $\mathrm{N}$ (urea) at 30 $\mathrm{kg} / \mathrm{ha}$ was applied as a top dressing approximately 4 weeks after planting.

Genotypes were reevaluated in 2004 in different plots from those used in the previous season to determine their consistency in field reaction to Fusarium stalk rot under natural and artificial disease conditions. Seeds ( 2 per hill) were sown manually on 15 June at Ibadan and 8 June at Ikenne, in single-row plots $5 \mathrm{~m}$ in length with 20 hills per row as described above, and treatments arranged in an augmented experimental design. Rows were spaced $0.75 \mathrm{~m}$ apart and the distance between hills was $0.25 \mathrm{~m}$. At both locations, inbred lines and the four checks were arranged in an augmented experimental design. Cultural practices at the two locations were similar in both years, except that fields at both sites were sprinkler irrigated three times a week during the drier month of August 2004.

Inoculum preparation and inoculation at Ibadan. Toothpicks colonized by $F$. verticillioides (American Type Culture Collection MYA 836) were used as the inoculum for stalk inoculation when inbred lines were evaluated for resistance to Fusarium stalk rot under artificial infection (10) at Ibadan. Toothpick inoculum was produced as previously described by Jardine and Leslie (19). Briefly, wooden toothpicks were boiled for about $1 \mathrm{~h}$ to remove ceresin that can inhibit growth of Fusarium spp. (34) and then air dried. Dry toothpicks were packed in a $250-\mathrm{ml}$ conical flask and $20 \mathrm{ml}$ of modified CzapekDox complete medium (7) was dispensed into the flasks to moisten the toothpicks. The flasks were plugged with cotton wool, covered with aluminum foil, and autoclaved at $121^{\circ} \mathrm{C}$ for $15 \mathrm{~min}$. After cooling, 2 $\mathrm{ml}$ of inoculum suspension $\left(1 \times 10^{6} \mathrm{co}-\right.$ nidia/ml) was injected into each flask and shaken to ensure that the toothpicks therein were uniformly coated with the mixture of agar and $F$. verticillioides spores. Inoculated flasks then were incubated at $25^{\circ} \mathrm{C}$ under 12 $\mathrm{h}$ of diurnal fluorescent light for 7 days.

Plants were inoculated at anthesis, approximately 7 weeks after planting. Steril- ized 1.8-mm-diameter nails on mounted wooden handles were used to make a 1 - to 2-cm-deep hole in the stalk at the third elongated internode and a toothpick colonized with $F$. verticillioides was inserted into the hole.

Disease assessment and inbred classification. Inbred lines were assessed for stalk rot at physiological maturity (R6), about

Table 1. Intensity of Fusarium stalk rot observed in maize genotypes artificially infected by Fusarium verticillioides at Ibadan, Nigeria, in the 2003 and 2004 growing seasons ${ }^{\mathrm{y}}$

\begin{tabular}{|c|c|c|c|c|}
\hline \multirow[b]{2}{*}{ Inbred line, hybrid ${ }^{\mathbf{z}}$} & \multicolumn{2}{|c|}{2003} & \multicolumn{2}{|c|}{2004} \\
\hline & SS & SD $(\%)$ & SS & SD $(\%)$ \\
\hline $02 \mathrm{C} 14582$ & 5.0 & 15.9 & 4.5 & 12.6 \\
\hline $02 \mathrm{C} 14583$ & 5.0 & 14.4 & 4.0 & 20.6 \\
\hline $02 \mathrm{C} 14585$ & 5.0 & 31.4 & 4.4 & 9.6 \\
\hline $02 \mathrm{C} 14588$ & 5.0 & 15.6 & 5.0 & 15.2 \\
\hline $02 \mathrm{C} 14589$ & 5.0 & 24.2 & 4.4 & 12.9 \\
\hline $02 \mathrm{C} 14593$ & 5.0 & 25.3 & 3.8 & 9.7 \\
\hline $02 \mathrm{C} 14595$ & 5.0 & 33.8 & 4.1 & 8.6 \\
\hline $02 \mathrm{C} 14596$ & 5.0 & 24.4 & 4.0 & 9.3 \\
\hline $02 \mathrm{C} 14699$ & $\ldots$ & $\ldots$ & 3.7 & 8.1 \\
\hline $02 \mathrm{C} 14601$ & 5.0 & 14.0 & 3.8 & 10.8 \\
\hline $02 \mathrm{C} 14603$ & 2.0 & 5.2 & 3.7 & 11.7 \\
\hline $02 \mathrm{C} 14605$ & 5.0 & 16.4 & 2.0 & 11.0 \\
\hline $02 \mathrm{C} 14606$ & $\ldots$ & $\ldots$ & 4.5 & 11.1 \\
\hline $02 \mathrm{C} 14607$ & 5.0 & 16.8 & 4.8 & 14.1 \\
\hline $02 \mathrm{C} 14609$ & 4.0 & 10.5 & 3.0 & 6.0 \\
\hline $02 \mathrm{C} 14611$ & 5.0 & 26.1 & 4.9 & 14.2 \\
\hline $02 \mathrm{C} 14613$ & 5.0 & 12.1 & 4.0 & 8.0 \\
\hline $02 \mathrm{C} 14616$ & 5.0 & 19.0 & 3.7 & 9.1 \\
\hline $02 \mathrm{C} 14617$ & 4.0 & 10.3 & 4.8 & 9.8 \\
\hline $02 \mathrm{C} 14618$ & 3.0 & 5.8 & 4.6 & 9.4 \\
\hline $02 \mathrm{C} 14619$ & 1.0 & 4.6 & 2.0 & 6.9 \\
\hline $02 \mathrm{C} 14621$ & 5.0 & 14.8 & 5.0 & 10.7 \\
\hline $02 \mathrm{C} 14622$ & 5.0 & 17.7 & 3.0 & 6.0 \\
\hline $02 \mathrm{C} 14624$ & 4.5 & 13.7 & 4.5 & 9.0 \\
\hline $02 \mathrm{C} 14626$ & 4.0 & 9.2 & 3.8 & 8.3 \\
\hline $02 \mathrm{C} 14627$ & 1.0 & 3.8 & 3.4 & 7.4 \\
\hline $02 \mathrm{C} 14628$ & 5.0 & 12.6 & 2.2 & 5.4 \\
\hline $02 \mathrm{C} 14629$ & 5.0 & 12.1 & 4.3 & 12.8 \\
\hline $02 \mathrm{C} 14637$ & 5.0 & 15.8 & 2.3 & 5.2 \\
\hline $02 \mathrm{C} 14640$ & 4.0 & 9.4 & 4.8 & 10.3 \\
\hline $02 \mathrm{C} 14643$ & 1.0 & 4.0 & 1.8 & 4.4 \\
\hline $02 \mathrm{C} 14645$ & 5.0 & 24.6 & 5.0 & 11.4 \\
\hline $02 \mathrm{C} 14646$ & 4.0 & 10.1 & 3.6 & 8.9 \\
\hline $02 \mathrm{C} 14649$ & $\ldots$ & & 2.8 & 5.5 \\
\hline $02 \mathrm{C} 14651$ & 5.0 & 17.2 & $\ldots$ & $\ldots$ \\
\hline $02 \mathrm{C} 14653$ & 1.0 & 4.8 & 1.6 & 4.6 \\
\hline $02 \mathrm{C} 14654$ & & & 1.6 & 5.0 \\
\hline $02 \mathrm{C} 14655$ & 3.0 & 7.0 & 3.2 & 9.0 \\
\hline $02 \mathrm{C} 14656$ & 5.0 & 15.8 & 3.7 & 9.7 \\
\hline $02 \mathrm{C} 14661$ & 5.0 & 12.5 & 3.9 & 6.7 \\
\hline $02 \mathrm{C} 14663$ & 4.0 & 8.8 & 4.7 & 11.0 \\
\hline $02 \mathrm{C} 14667$ & 4.0 & 10.3 & 5.0 & 10.0 \\
\hline $02 \mathrm{C} 16470$ & 4.0 & 10.4 & 5.0 & 13.1 \\
\hline $02 \mathrm{C} 14671$ & 2.0 & 6.2 & 3.5 & 13.3 \\
\hline $02 \mathrm{C} 14675$ & 5.0 & 21.6 & 5.0 & 13.4 \\
\hline $02 \mathrm{C} 14677$ & 4.0 & 8.4 & 2.2 & 7.0 \\
\hline $02 \mathrm{C} 14678$ & 4.0 & 9.2 & 2.8 & 7.9 \\
\hline $02 \mathrm{C} 14679$ & 5.0 & 22.1 & 2.4 & 6.8 \\
\hline $02 \mathrm{C} 14680$ & 5.0 & 12.4 & 3.3 & 8.1 \\
\hline $02 \mathrm{C} 14683$ & 5.0 & 18.1 & 3.8 & 7.9 \\
\hline Oba super 1 & 4.2 & 16.9 & 4.5 & 11.8 \\
\hline Oba super 2 & 4.6 & 17.7 & 4.1 & 12.0 \\
\hline $9031-29$ & 5.0 & 14.3 & 4.5 & 12.2 \\
\hline AK9443DMRSR & 4.2 & 12.6 & 4.2 & 12.0 \\
\hline Mean & 4.2 & 14.4 & 3.7 & 9.7 \\
\hline $\operatorname{LSD}(\alpha=0.05)$ & 2.9 & 29.1 & 1.8 & 7.3 \\
\hline
\end{tabular}

y $\mathrm{SS}=$ severity score and $\mathrm{SD}=$ stalk discoloration. Stalk rot was visually assessed at harvest using a 1 to 5 severity scale (16), where $1=0$ to $25 \%, 2=26$ to $50 \%, 3=51$ to $75 \%, 4=76$ to $100 \%$, and $5=$ $100 \%$ rot, with infection extending into an adjacent internode; $\ldots=$ no data.

${ }^{\mathrm{z}}$ Oba super 1, Oba super 2, and 9031-29 are hybrids while AK9443DMRSR is an open-pollinated cultivar. LSD = least significant difference. 
15 weeks after planting. Assessment was done by arbitrarily selecting 10 stalks from each row, leaving out the first and the last plants to avoid border effects. Stalks were excised at the soil line and trimmed back to four internodes above the ear nodes. Longitudinally split stalks then were rated individually for stalk rot severity. Estimation of severity was based on 1 to 5 stalk rot severity scale (SS) according to Hooker (16), where $1=0$ to $25 \%$ rot, $2=26$ to $50 \%$ rot, $3=51$ to $75 \%$ rot, $4=76$ to $100 \%$ rot, and $5=$ $100 \%$ rot with infection extending into an adjacent internode. In addition, the split stalks were evaluated for the length $(\mathrm{cm})$ of stalk discoloration as described by Gatch et al. (12). The severity of stalk discoloration (SD) then was calculated by expressing the length of discoloration as a proportion of the length of the four internodes multiplied by 100. Data on SS and SD were combined and used to separate inbred lines into various levels of stalk rot resistance (described below).

Weather data during the experimental period at Ibadan and Ikenne locations was obtained from IITA Geo-Spatial Unit,
Ibadan, Oyo State and the Nigerian Meteorological Agency, Federal Secretariat, Abeokuta, Ogun State, respectively.

Statistical analysis. In 2003, effects of years and inbred lines on Fusarium stalk rot severity (SS and SD) data collected from the augmented experimental design were analyzed using the PROC MIXED procedure of SAS as described by Wolfinger et al. (37). In the statistical model, years were considered random while inbred lines were considered as fixed effects. Data from individual years were analyzed and presented separately if a significant inbred-year interaction was detected for either SS or SD. Differences between inbred lines within years were determined using Fisher's protected least significant difference (LSD) test. Simple linear correlation was used to determine the relationship between SS and SD. Linear correlations were performed separately for each location using the CORR procedure in SAS.

The rank-sum method $(3,28)$ was used to classify inbred lines into different categories of resistance based on the means of SS and SD for each inbred across the 2 years of the study. Specifically, to calculate the rank-sum, the mean SS and SD for the inbred lines were assigned ranks from the smallest to the largest using the RANK procedure of the SAS. The sum of the ranks $\left(X_{\mathrm{n}}\right)$ was computed for each of the inbred line and compared with the grand mean of the rank-sums across all the inbred lines $\left(G_{\mathrm{n}}\right)$. Deviation of each inbred from the grand mean was calculated as $\left(\left[X_{\mathrm{n}}-G_{\mathrm{n}}\right] /\right.$ standard deviation $) \times 2$. Deviations to the right (positive) of the grand mean on the mean distribution curve were rated susceptible while deviations to the left (negative) of the grand mean were rated resistant. Inbreds with 1,2 , and 3 deviations to the right of $G_{\mathrm{n}}$ were classified as moderately susceptible, susceptible, and highly susceptible, respectively, while inbreds with $-1,-2$, and -3 deviations to the left of $G_{\mathrm{n}}$ were classified as moderately resistant, resistant, and highly resistant, respectively (28). The distribution of the genotypes based on the rank-sum was tested for normality using the PROC UNIVARIATE procedure in SAS. All statistical analyses were performed in SAS (version 9.1; SAS Institute, Cary, NC).
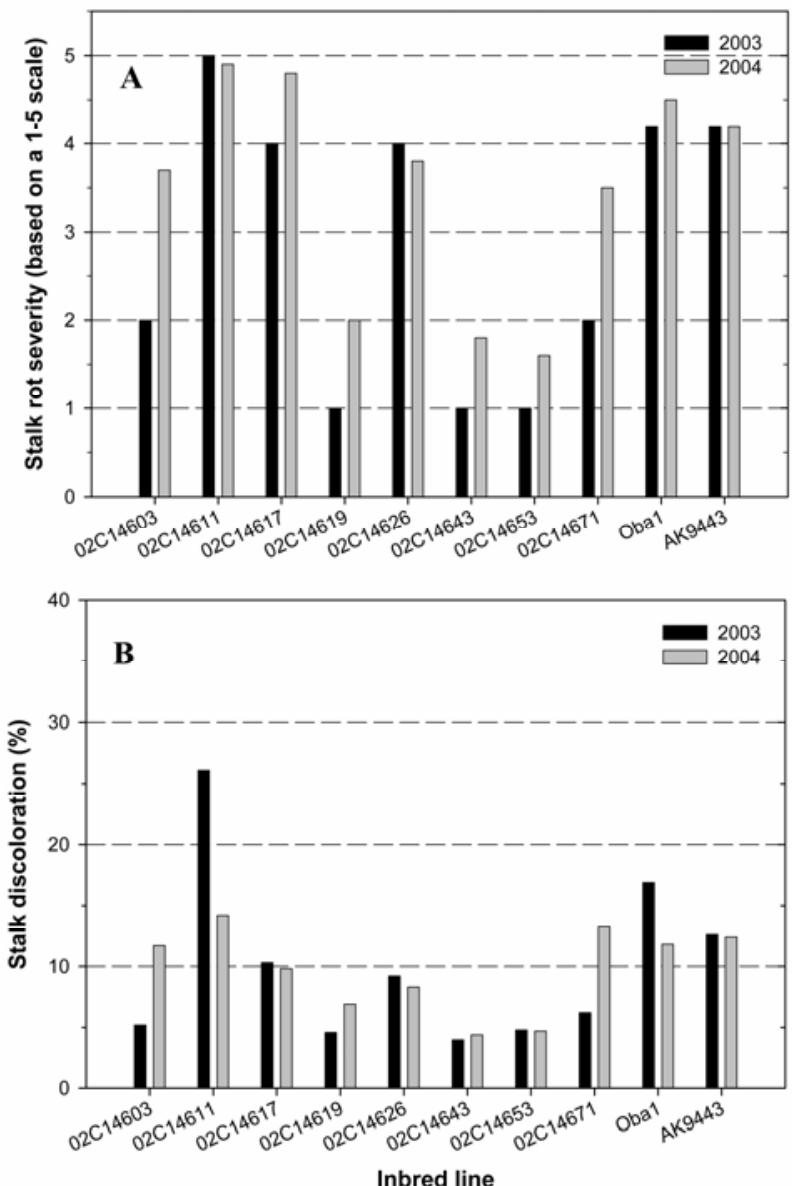

Fig. 1. Intensity of Fusarium stalk rot for a subset of maize inbred lines planted at the International Institute of Tropical Agriculture experimental site at Ibadan, Nigeria, during the rainy seasons in 2003 and 2004. Disease was assessed using A, a 1 to 5 severity rating scale and $\mathbf{B}$, direct assessment of stalk discoloration following artificial inoculation of stalks 2 weeks after tasseling. Depicted inbred lines are selected to illustrate consistency in disease reaction across the 2 years.
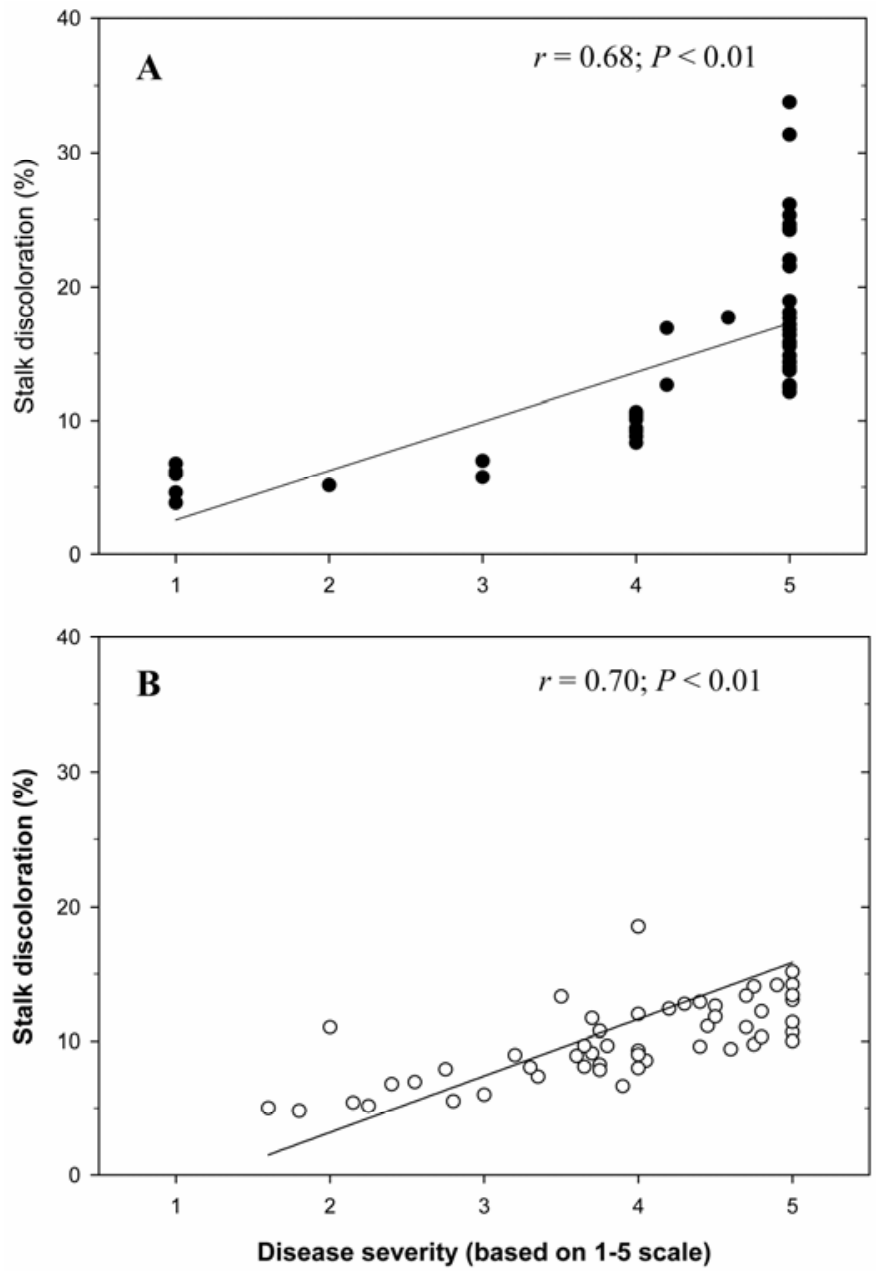

Fig. 2. Linear correlation of Fusarium stalk rot assessments based on severity rating scale and direct assessment of stalk discoloration (\%) following artificial inoculation of stalks 2 weeks after tasseling at Ibadan, Nigeria in A, 2003 and $\mathbf{B}, 2004$ rainy seasons. 


\section{RESULTS}

Evaluation under artificial infection at Ibadan. Fusarium stalk rot was observed on all the inbred lines and hybrid checks following artificial inoculation. In 2003, SS ranged from 1.0 to 5.0 with a mean of 4.2, and the corresponding levels of disease severity based on SD ranged from 3.8 to $33.8 \%$ with a mean of $14.4 \%$. In 2004, mean disease severity based on SS and SD was 3.7 (range 1.6 to 5.0) and $9.7 \%$ (range 4.4 to $20.6 \%$ ), respectively (Table 1). Mean SS and SD was significantly $(P<0.01)$ higher in 2003 than in 2004. Unlike at the Ikenne site, a significant $(P=0.01)$ inbred-year interaction was observed only when stalk rot was assessed based on SD. No significant $(P>$ 0.05 ) inbred-year interaction was detected when disease was assessed using SS.

In 2003, severity of Fusarium stalk rot differed significantly among inbred lines when disease was assessed using either SS $(P=0.02)$ or SD $(P=0.04)$. Further, inbred lines 02C14619, 02C14627, $02 \mathrm{C} 14643$, and $02 \mathrm{C} 14653$ had significantly $(P<0.05)$ lower levels of SS than all other genotypes except 02C14603, 02C14618, 02C14671, and 02C14655. When stalk rot was assessed using SD, inbred lines 02C14619, 02C14627, and $02 \mathrm{C} 14643$ had significantly $(P<0.05)$ lower levels of SD than 02C14595, which had the highest level of SD (Table 1). Significant effects of inbred lines on disease severity also were observed in 2004, when disease was assessed using SS $(P=0.01)$ and SD $(P=0.04)$. Inbred lines $02 \mathrm{C} 14643$ and $02 \mathrm{C} 14653$ had significantly $(P<0.05)$ lower levels of stalk rot $(<4.8 \%)$ than the check hybrid Oba super 2 (12\%), when disease was assessed using SD in 2004 (Table 1). The highest level of SD was observed on $02 \mathrm{C} 14583$ with a disease severity of $20.6 \%$. When disease was assessed using SS in 2004, eight inbred lines (02C14605, 02C14619, 02C14628, 02C14637, 02C14643, 02C14653, 02C14654, and 02C14677) had significantly $(P<0.05)$ lower disease levels than Oba super 2.

Across the 2 years, inbred lines 02C14619, 02C14643, and 02C14653 had consistently low levels of disease severity when stalk rot was assessed using both SS and SD methods (Fig. 1). In addition, disease assessments based on SS were significantly linearly correlated $(r=0.68$ to $0.70 ; P<0.01)$ with assessments based on $\mathrm{SD}$ in both years (Fig. 2).

Classification of genotypes using the rank-sum analysis showed that $6(11.1 \%)$ inbred lines were highly resistant, 8 (17.1\%) were resistant, and 11 (20.4\%) were moderately resistant to stalk rot (Table 2). In all, 1 inbred line (1.9\%) was highly susceptible; $10(18.5 \%)$ were susceptible; and $14(33.3 \%)$, including three check hybrids and the open pollinated cv. AK9443DMRSR, were moderately sus- ceptible to stalk rot (Table 2). Frequency distribution of all the genotypes, classified based on their level of resistance to Fusarium stalk rot, appeared to be continuous and the Shapiro-Wilk test $(P=0.09)$ did not indicate departure from normality.

Evaluation under natural infection at Ikenne. In 2003, SS ranged from 1 to 5 with a mean of 2.4 , while SD ranged from 1.3 to $15.5 \%$ with a mean of $5.6 \%$. In 2004, SS ranged from 1.0 to 5.0 with a mean of 1.3 and SD ranged from 0 to

Table 2. Standardized average Fusarium stalk rot ratings of maize genotypes with different levels of disease resistance at Ibadan, Nigeria, as identified by the rank-sum classification method ${ }^{\mathrm{w}}$

\begin{tabular}{|c|c|c|c|c|c|c|c|}
\hline \multirow[b]{2}{*}{ Inbred line, hybrid ${ }^{x}$} & \multicolumn{2}{|c|}{ SS } & \multicolumn{2}{|c|}{ Discoloration score } & \multicolumn{2}{|c|}{ Genotype ranking } & \multirow[b]{2}{*}{ Class $^{\mathrm{y}}$} \\
\hline & SS & $a$ & SD & $b$ & $c$ & $d$ & \\
\hline $02 \mathrm{C} 14643$ & 1.4 & 2 & 4.2 & 1 & 3 & -3.7 & HR \\
\hline $02 \mathrm{C} 14653$ & 1.3 & 1 & 4.7 & 2 & 3 & -3.7 & HR \\
\hline $02 \mathrm{C} 14654$ & 1.6 & 4 & 5.0 & 3 & 7 & -3.6 & HR \\
\hline $02 \mathrm{C} 14619$ & 1.5 & 3 & 5.8 & 6 & 9 & -3.4 & HR \\
\hline $02 \mathrm{C} 14627$ & 2.2 & 5 & 5.6 & 5 & 10 & -3.3 & HR \\
\hline $02 \mathrm{C} 14649$ & 2.8 & 6 & 5.5 & 4 & 10 & -3.3 & HR \\
\hline $02 \mathrm{C} 14655$ & 3.1 & 9 & 8.0 & 9 & 18 & -2.6 & $\mathrm{R}$ \\
\hline $02 \mathrm{C} 14677$ & 3.3 & 10 & 7.7 & 8 & 18 & -2.6 & $\mathrm{R}$ \\
\hline $02 \mathrm{C} 14603$ & 2.9 & 8 & 8.5 & 12 & 20 & -2.4 & $\mathrm{R}$ \\
\hline $02 \mathrm{C} 14609$ & 3.5 & 12 & 8.3 & 11 & 23 & -2.2 & $\mathrm{R}$ \\
\hline $02 \mathrm{C} 14618$ & 3.8 & 16 & 7.6 & 7 & 23 & -2.2 & $\mathrm{R}$ \\
\hline $02 \mathrm{C} 14678$ & 3.4 & 11 & 8.6 & 13 & 24 & -2.1 & $\mathrm{R}$ \\
\hline $02 \mathrm{C} 14599$ & 3.7 & 15 & 8.1 & 10 & 25 & -2.0 & $\mathrm{R}$ \\
\hline $02 \mathrm{C} 14671$ & 2.8 & 7 & 9.8 & 18 & 25 & -2.0 & $\mathrm{R}$ \\
\hline $02 \mathrm{C} 14628$ & 3.6 & 13 & 9.0 & 15 & 28 & -1.7 & MR \\
\hline $02 \mathrm{C} 14626$ & 3.9 & 18 & 8.8 & 14 & 32 & -1.4 & MR \\
\hline $02 \mathrm{C} 14646$ & 3.9 & 17 & 9.5 & 16 & 33 & -1.3 & MR \\
\hline $02 \mathrm{C} 14637$ & 3.7 & 14 & 10.5 & 24 & 38 & -0.9 & MR \\
\hline $02 \mathrm{C} 14663$ & 4.4 & 22 & 9.9 & 19 & 41 & -0.6 & MR \\
\hline $02 \mathrm{C} 14661$ & 4.5 & 25 & 9.6 & 17 & 42 & -0.5 & MR \\
\hline $02 \mathrm{C} 14680$ & 4.2 & 19 & 10.3 & 23 & 42 & -0.5 & MR \\
\hline $02 \mathrm{C} 14640$ & 4.4 & 24 & 9.9 & 19 & 43 & -0.4 & MR \\
\hline $02 \mathrm{C} 14617$ & 4.4 & 24 & 10.1 & 21 & 45 & -0.2 & MR \\
\hline $02 \mathrm{C} 14613$ & 4.5 & 26 & 10.0 & 20 & 46 & -0.2 & MR \\
\hline $02 \mathrm{C} 14605$ & 3.5 & 12 & 13.7 & 35 & 47 & -0.1 & MR \\
\hline $02 \mathrm{C} 14667$ & 4.5 & 26 & 10.2 & 22 & 48 & 0.0 & MS \\
\hline AK9443DMRSR & 4.2 & 20 & 12.3 & 28 & 48 & 0.0 & MS \\
\hline $02 \mathrm{C} 14606$ & 4.5 & 26 & 11.1 & 25 & 51 & 0.3 & MS \\
\hline $02 \mathrm{C} 14624$ & 4.5 & 26 & 11.4 & 26 & 52 & 0.4 & MS \\
\hline $02 \mathrm{C} 14601$ & 4.4 & 24 & 12.4 & 29 & 53 & 0.5 & MS \\
\hline $02 \mathrm{C} 14656$ & 4.4 & 21 & 12.9 & 32 & 53 & 0.5 & MS \\
\hline $02 \mathrm{C} 14670$ & 4.5 & 26 & 11.8 & 27 & 53 & 0.5 & MS \\
\hline $02 \mathrm{C} 14679$ & 3.7 & 15 & 14.5 & 39 & 54 & 0.5 & MS \\
\hline $02 \mathrm{C} 14616$ & 4.4 & 21 & 14.1 & 36 & 57 & 0.8 & MS \\
\hline $02 \mathrm{C} 14683$ & 4.4 & 24 & 13.0 & 33 & 57 & 0.8 & MS \\
\hline $02 \mathrm{C} 14629$ & 4.7 & 28 & 12.5 & 30 & 58 & 0.9 & MS \\
\hline $9031-29$ & 4.8 & 30 & 13.2 & 34 & 64 & 1.4 & MS \\
\hline Oba super 2 & 4.4 & 24 & 14.9 & 31 & 64 & 1.4 & MS \\
\hline $02 \mathrm{C} 14621$ & 5.0 & 33 & 12.8 & 40 & 64 & 1.4 & MS \\
\hline Oba super 1 & 4.5 & 26 & 14.6 & 39 & 65 & 1.5 & MS \\
\hline $02 \mathrm{C} 14582$ & 4.8 & 30 & 14.3 & 37 & 67 & 1.7 & MS \\
\hline $02 \mathrm{C} 14593$ & 4.4 & 23 & 17.5 & 45 & 68 & 1.8 & MS \\
\hline $02 \mathrm{C} 14596$ & 4.5 & 26 & 16.9 & 43 & 69 & 1.8 & MS \\
\hline $02 \mathrm{C} 14583$ & 4.5 & 26 & 17.5 & 45 & 71 & 2.0 & S \\
\hline $02 \mathrm{C} 14607$ & 4.9 & 31 & 15.5 & 42 & 73 & 2.2 & $\mathrm{~S}$ \\
\hline $02 \mathrm{C} 14588$ & 5.0 & 33 & 15.4 & 41 & 74 & 2.3 & $\mathrm{~S}$ \\
\hline $02 \mathrm{C} 14651$ & 5.0 & 33 & 17.2 & 44 & 77 & 2.5 & $\mathrm{~S}$ \\
\hline $02 \mathrm{C} 14589$ & 4.7 & 29 & 18.6 & 49 & 78 & 2.6 & $\mathrm{~S}$ \\
\hline $02 \mathrm{C} 14595$ & 4.6 & 27 & 21.2 & 52 & 79 & 2.7 & $S$ \\
\hline $02 \mathrm{C} 14675$ & 5.0 & 33 & 17.6 & 46 & 79 & 2.7 & $\mathrm{~S}$ \\
\hline $02 \mathrm{C} 14585$ & 4.7 & 29 & 20.5 & 51 & 80 & 2.8 & $\mathrm{~S}$ \\
\hline $02 \mathrm{C} 14622$ & 5.0 & 33 & 17.7 & 47 & 80 & 2.8 & $\mathrm{~S}$ \\
\hline $02 \mathrm{C} 14645$ & 5.0 & 33 & 18.0 & 48 & 81 & 2.9 & $\mathrm{~S}$ \\
\hline $02 \mathrm{C} 14611$ & 5.0 & 32 & 20.2 & 50 & 82 & 3.0 & HS \\
\hline Mean & 3.9 & $\ldots$ & 12.3 & $\ldots$ & $46.8^{z}$ & $\ldots$ & $\ldots$ \\
\hline
\end{tabular}

${ }^{\mathrm{w}} \mathrm{SS}=$ severity score (mean of 2 years' data) based on a 1 to 5 scale and SD = stalk discoloration (\%), mean of the 2 years' data; $a=$ inbred ranking using SS; $b=$ genotype ranking using SD; $c=$ rank-sum $(a+b)$ for each inbred; $d=$ deviation from the grand mean $(\mathrm{G})$ of the rank-sums $([d=(c-$ $\mathrm{G}) /$ standard deviation] $\times 2$ ).

${ }^{x}$ Oba super 1, Oba super 2, and 9031-29 are hybrids, while AK9443DMRSR is an open-pollinated cultivar.

${ }^{\mathrm{y}} \mathrm{HR}=$ highly resistant, $\mathrm{R}=$ resistant, $\mathrm{MR}=$ moderately resistant, $\mathrm{MS}=$ moderately susceptible, $\mathrm{S}=$ susceptible, and HS = highly susceptible.

${ }^{\mathrm{z}}$ Grand mean of the rank-sums $(\mathrm{G})$. 
$11.0 \%$ (Table 3) with a mean of $1.7 \%$. Both SS and SD were significantly $(P<$ 0.01 ) higher in 2003 than in 2004. A significant inbred-year interaction also was observed when stalk rot was assessed based on SS $(P<0.01)$ and SD $(P<0.05)$.

Fusarium stalk rot severity differed significantly among genotypes in 2003 when disease was assessed using either SS $(P=$
$0.03)$ or $\mathrm{SD}(P=0.04)$. Inbred lines 02C14605, 02C14619, 02C1453, and $02 \mathrm{C} 14661$ were among those that had significantly $(P<0.05)$ lower SS than 02C14603, which had the highest SS. When stalk rot was assessed using SD, inbred lines 02C14605, 02C14621, $02 \mathrm{C} 14653$, and $02 \mathrm{C} 14678$ had $<2.0 \% \mathrm{SD}$, which was significantly $(P<0.05)$ lower

Table 3. Intensity of Fusarium stalk rot observed on maize inbred lines naturally infected by Fusarium verticillioides at Ikenne, Nigeria, in 2003 and $2004^{\mathrm{y}}$

\begin{tabular}{|c|c|c|c|c|}
\hline \multirow[b]{2}{*}{ Inbred line, hybrid ${ }^{\mathrm{z}}$} & \multicolumn{2}{|c|}{2003} & \multicolumn{2}{|c|}{2004} \\
\hline & SS & SD $(\%)$ & SS & SD $(\%)$ \\
\hline $02 \mathrm{C} 14582$ & 4.0 & 10.3 & 1.0 & 0.0 \\
\hline $02 \mathrm{C} 14583$ & 4.0 & 9.4 & 1.0 & 1.9 \\
\hline $02 \mathrm{C} 14585$ & 2.0 & 4.7 & 1.0 & 0.0 \\
\hline $02 \mathrm{C} 14588$ & 2.0 & 4.0 & 1.0 & 0.0 \\
\hline $02 \mathrm{C} 14589$ & 1.0 & 2.1 & 1.0 & 0.0 \\
\hline $02 \mathrm{C} 14593$ & 4.0 & 8.5 & 1.0 & 1.2 \\
\hline $02 \mathrm{C} 14595$ & 1.0 & 2.1 & 1.0 & 0.6 \\
\hline $02 \mathrm{C} 14596$ & 2.0 & 3.8 & 1.0 & 2.4 \\
\hline $02 \mathrm{C} 14599$ & 4.0 & 10.7 & 1.0 & 2.0 \\
\hline $02 \mathrm{C} 14601$ & 4.0 & 8.4 & 1.7 & 4.4 \\
\hline $02 \mathrm{C} 14603$ & 5.0 & 15.5 & 2.9 & 6.3 \\
\hline $02 \mathrm{C} 14605$ & 1.0 & 1.3 & 1.0 & 0.0 \\
\hline $02 \mathrm{C} 14606$ & 1.0 & 0.0 & 3.0 & 7.8 \\
\hline $02 \mathrm{C} 14607$ & 1.0 & 2.8 & 1.0 & 1.3 \\
\hline $02 \mathrm{C} 14609$ & $\ldots$ & $\ldots$ & 1.0 & 0.0 \\
\hline $02 \mathrm{C} 14611$ & 2.0 & 3.2 & 2.0 & 3.4 \\
\hline $02 \mathrm{C} 14613$ & 2.0 & 4.8 & 1.0 & 4.9 \\
\hline $02 \mathrm{C} 14616$ & 3.0 & 6.7 & 1.0 & 1.0 \\
\hline $02 \mathrm{C} 14617$ & 3.0 & 6.1 & 2.7 & 6.9 \\
\hline $02 \mathrm{C} 14618$ & 3.0 & 7.7 & 1.0 & 0.0 \\
\hline $02 \mathrm{C} 14619$ & 1.0 & 2.5 & 1.0 & 2.8 \\
\hline $02 \mathrm{C} 14621$ & 1.0 & 1.5 & 1.0 & 0.7 \\
\hline $02 \mathrm{C} 14622$ & 1.0 & 2.4 & 1.0 & 0.0 \\
\hline $02 \mathrm{C} 14624$ & 2.0 & 5.2 & 1.0 & 0.0 \\
\hline $02 \mathrm{C} 14626$ & 2.0 & 4.8 & 1.0 & 0.9 \\
\hline $02 \mathrm{C} 14627$ & 4.0 & 11.3 & 1.0 & 0.0 \\
\hline $02 \mathrm{C} 14628$ & 3.0 & 6.3 & 1.0 & 0.0 \\
\hline $02 \mathrm{C} 14629$ & 3.0 & 6.2 & 1.0 & 0.0 \\
\hline $02 \mathrm{C} 14637$ & 4.0 & 8.2 & 4.0 & 11.0 \\
\hline $02 \mathrm{C} 14640$ & 2.0 & 4.0 & 1.0 & 0.0 \\
\hline $02 \mathrm{C} 14643$ & $\ldots$ & $\ldots$ & 1.0 & 1.0 \\
\hline $02 \mathrm{C} 14645$ & 3.0 & 6.9 & 1.0 & 0.0 \\
\hline $02 \mathrm{C} 14646$ & 3.0 & 6.3 & 1.0 & 0.4 \\
\hline $02 \mathrm{C} 14649$ & 1.0 & 2.2 & 1.0 & 0.5 \\
\hline $02 \mathrm{C} 14651$ & $\ldots$ & $\ldots$ & 1.0 & 0.0 \\
\hline $02 \mathrm{C} 14653$ & 1.0 & 1.8 & 1.5 & 1.9 \\
\hline $02 \mathrm{C} 14654$ & $\ldots$ & $\ldots$ & 1.0 & 0.0 \\
\hline $02 \mathrm{C} 14655$ & $\ldots$ & $\ldots$ & 1.5 & 3.0 \\
\hline $02 \mathrm{C} 14656$ & 2.0 & 4.3 & 1.5 & 2.6 \\
\hline $02 \mathrm{C} 14661$ & 1.0 & 2.7 & 1.0 & 1.7 \\
\hline $02 \mathrm{C} 14663$ & $\ldots$ & $\ldots$ & 1.0 & 2.1 \\
\hline $02 \mathrm{C} 14667$ & 2.0 & 4.6 & 1.0 & 0.0 \\
\hline $02 \mathrm{C} 14670$ & $\ldots$ & $\ldots$ & 1.0 & 0.7 \\
\hline $02 \mathrm{C} 14671$ & 4.0 & 7.5 & 2.0 & 6.3 \\
\hline $02 \mathrm{C} 14675$ & 3.0 & 6.9 & 1.0 & 0.0 \\
\hline $02 \mathrm{C} 14677$ & 2.0 & 5.1 & 1.0 & 0.0 \\
\hline $02 \mathrm{C} 14678$ & 1.0 & 1.5 & 1.0 & 0.0 \\
\hline $02 \mathrm{C} 14679$ & 4.0 & 10.2 & 1.7 & 2.3 \\
\hline $02 \mathrm{C} 14680$ & $\ldots$ & $\ldots$ & 1.0 & 0.0 \\
\hline $02 \mathrm{C} 14683$ & $\ldots$ & $\ldots$ & 1.5 & 2.3 \\
\hline Oba super 1 & 2.5 & 6.0 & 2.0 & 6.1 \\
\hline Oba super 2 & 2.5 & 5.5 & 1.0 & 0.0 \\
\hline $9031-29$ & 3.2 & 6.8 & 1.0 & 0.0 \\
\hline AK9443DMRSR & 3.3 & 8.0 & 2.0 & 3.5 \\
\hline Mean & 2.4 & 5.6 & 1.3 & 1.7 \\
\hline $\operatorname{LSD}(\alpha=0.05)$ & 3.8 & 7.3 & 2.8 & 5.5 \\
\hline
\end{tabular}

${ }^{\text {y }} \mathrm{SS}=$ severity score and $\mathrm{SD}=$ stalk discoloration. Stalk rot was visually assessed at harvest using a 1 to 5 severity scale (16), where $1=0$ to $25 \%, 2=26$ to $50 \%, 3=51$ to $75 \%, 4=76$ to $100 \%$, and $5=$ $100 \%$ rot, with infection extending into an adjacent internode; $\ldots=$ no data.

${ }^{\mathrm{z}}$ Oba super 1, Oba super 2, and 9031-29 are hybrids, while AK9443DMRSR is an open-pollinated cultivar. LSD = least significant difference. than the highest level of SD (15.5\%) observed on $02 \mathrm{C} 14603$ (Table 3). Similar effects of inbred lines on stalk rot were observed in 2004, with significant differences in SS $(P<0.05)$ and SD $(P=0.02)$ (Table 3). In 2004, both SS and SD were generally lower on all inbred lines than disease levels observed in 2003. However, 02C14582, 02C14605, 02C14621, and $02 \mathrm{C} 14626$ were among the genotypes that had significantly $(P<0.05)$ lower levels of $\mathrm{SD}$ than the check cv. Oba super 1. The inbred line $02 \mathrm{C} 14637$ had a significantly $(P<0.05)$ higher level of SD than all the test genotypes except $02 \mathrm{C} 14603$ and 02C14617 (Table 3).

Across the 2 years, inbred lines such as 02C14619, 02C14621, and 02C14653 had consistently low levels of stalk rot when disease was assessed using both SS and SD (Fig. 3). Inbred line 02C14611 that had consistently low levels of SD did not have corresponding low levels of SS in both years. Disease assessments based on SS were significantly correlated $(r=0.87$ to $0.95 ; P<0.01)$ with assessments based on SD in both years (Fig. 4).

Based on the rank-sum analysis, 11 $(20.3 \%)$ inbred lines were resistant to stalk rot; $17(31.5 \%)$ genotypes, including the hybrid check Oba super 2, were moderately resistant; 16 genotypes and the hybrid check 9031-29 (31.5\%) were moderately susceptible; and $5(9.3 \%)$ and $4(7.4 \%)$ genotypes were susceptible and highly susceptible, respectively (Table 4). None of the inbred lines evaluated at this site was classified as highly resistant to stalk rot. Frequency distribution of all the genotypes appeared to be continuous and the Shapiro-Wilk test $(P$ $<0.05)$ did not indicate drastic departure from normality.

Weather data. Generally, mean monthly temperatures were similar across the 2 years at Ikenne during the experimental period between June and October, with a range between 25.8 and $27.5^{\circ} \mathrm{C}$ (Fig. 5A). Monthly rainfall amounts during the same period were consistently lower in 2003 and higher in 2004 except during the month of June, when $346 \mathrm{~mm}$ of rain was recorded in 2003 compared with $250 \mathrm{~mm}$ in 2004. Rainfall decreased from June to August and increased in September before slightly dropping at harvest in October (Fig. 5A). Mean monthly temperatures at Ibadan also were generally similar across the 2 years during the experimental period between June and October with a mean of $25.3^{\circ} \mathrm{C}$ except during the month of July, when the mean temperature dropped to $23^{\circ} \mathrm{C}$ in 2003 (Fig. 5B). At both sites, monthly rainfall amounts were consistently lower in 2003 and higher in 2004 except during the months of June at Ikenne and September at Ibadan, when considerably higher rainfall amounts were recorded in 2003 compared with 2004. 


\section{DISCUSSION}

Deployment of resistant genotypes is one of the most sustainable and effective strategies in the management of Fusarium stalk rot of maize (27). In this study, maize genotypes were evaluated at two locations in Nigeria to identify inbred lines that are resistant to Fusarium stalk rot. This study identified inbred lines with consistently low levels of disease severity across years and experimental locations. This is the first comprehensive study in Africa that systematically documents new sources of resistance to Fusarium stalk rot of maize. Inbred lines identified in this study can be useful sources of resistance for breeding maize with resistance to Fusarium stalk rot.

Inbred lines exhibited significant differences in Fusarium stalk rot in both years, with higher disease levels in 2003 than those in 2004. The difference in disease severity may be attributed to differences in environmental conditions affecting disease development. Although the warm temperatures during the growing seasons in both 2003 and 2004 were suitable for infection by $F$. verticillioides (29), the lower rainfall in 2003 than in 2004 for all months during the study period, except in June and October at Ikenne and September and October at Ibadan, was more favorable to stalk rot, because warm temperatures coupled with low rainfall amounts favor development of the disease $(9,32)$. High levels of stalk rot also were observed on inbred lines at Ibadan following artificial inoculation; however, low levels of disease severity were observed on inbred lines at Ikenne where disease was initiated from natural infection. Except for the month of September, lower rainfall amounts were recorded at Ibadan than at Ikenne and this could have contributed to higher levels of Fusarium stalk rot at Ibadan. Levels of stalk rot severity observed in this study are similar to those reported in previous studies $(12,14)$. However, the low disease levels observed at Ikenne could have some influence on the identification of resistant inbred lines at that site. Unlike natural infection, artificial inoculation generates larger variations in disease severity that facilitate selection of resistant genotypes (22).

Despite the differences in disease severity between the 2 years and two experi- mental locations, inbred lines 02C14619, $02 \mathrm{C} 14643$, and $02 \mathrm{C} 14653$ had consistently low levels of SS $(\leq 2)$ and SD $(<7 \%)$ across years and locations. A number of inbred lines with either low or high levels of disease severity in 2003 did not have a comparable level of disease severity when reevaluated in 2004 under natural or artificial infection. Such low reproducibility of reaction to maize stalk rot under field conditions has been reported previously (12,22).

Adequate disease assessment and evaluation procedures are critical for the identification of resistant genotypes. Several studies $(17,18,22)$ have recommended the use of artificial inoculation when evaluating maize genotypes for resistance to Fusarium stalk rot. Artificial inoculation generates enough disease pressure that allows for separation of genotypes relative to their levels of disease resistance. For example, the rank-sum method identified both highly resistant and resistant inbred lines when genotypes were artificially inoculated at Ibadan, whereas only resistant genotypes were identified when inbreds were evaluated under natural infec-
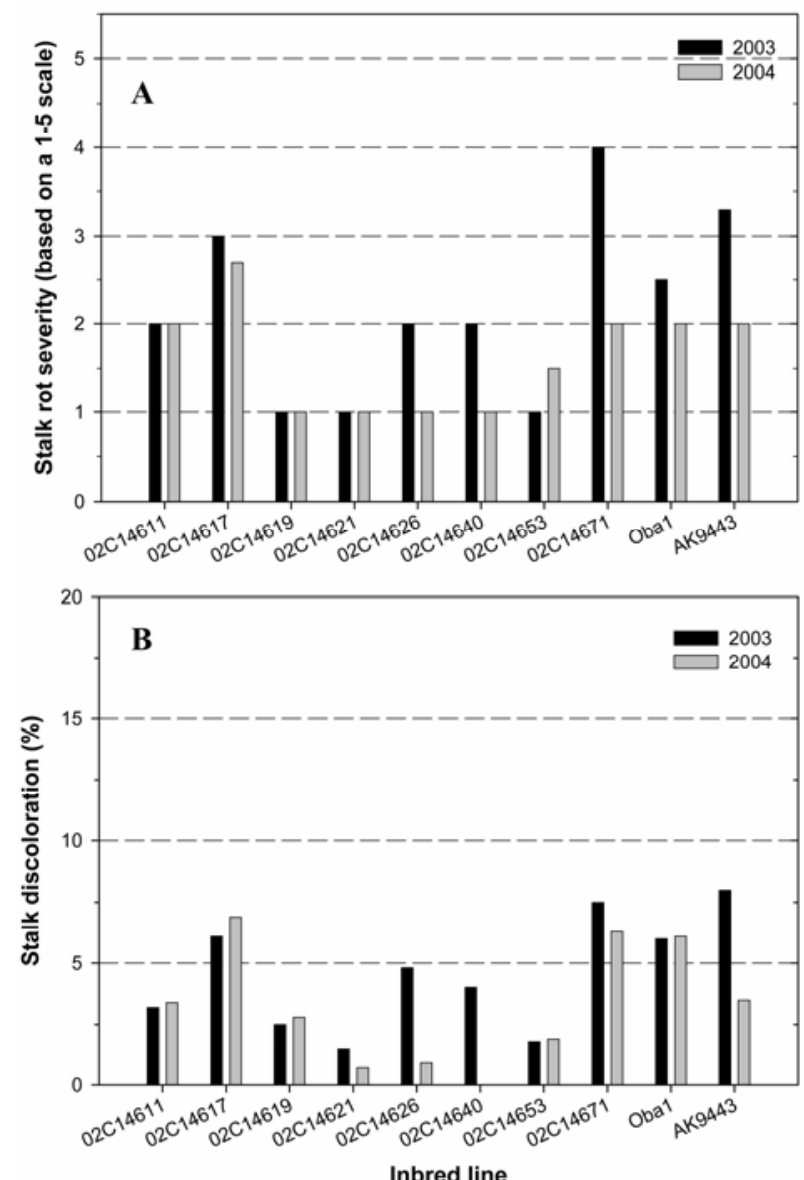

Fig. 3. Intensity of Fusarium stalk rot for a subset of maize inbred lines planted at the International Institute of Tropical Agriculture experimental site at Ikenne, Nigeria, during the rainy seasons in 2003 and 2004. Disease was assessed using $\mathbf{A}$, a 1 to 5 severity rating scale and B, direct assessment of stalk discoloration following natural infection. Depicted inbred lines are selected to illustrate consistency in disease reaction across the 2 years.
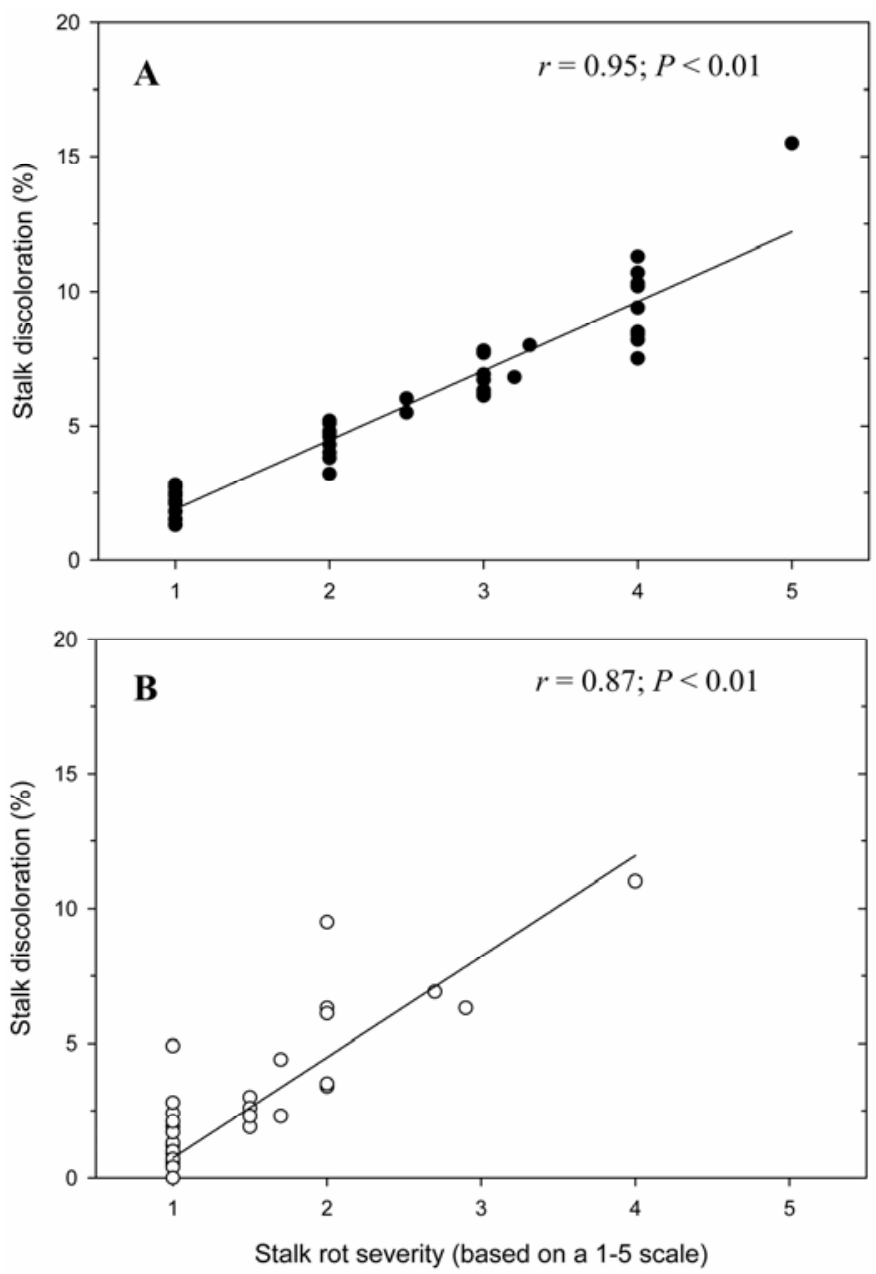

Fig. 4. Linear correlation of Fusarium stalk rot assessments based on severity rating scale and direct assessment of stalk discoloration (\%) under natural infection at Ikenne, Nigeria in $\mathbf{A}, 2003$ and B, 2004 rainy seasons. 
Table 4. Standardized average Fusarium stalk rot ratings of maize genotypes with different levels of disease resistance at Ikenne, Nigeria, as identified by the rank-sum classification method ${ }^{\mathrm{w}}$

\begin{tabular}{|c|c|c|c|c|c|c|c|}
\hline \multirow[b]{2}{*}{ Inbred line, hybrid ${ }^{x}$} & \multicolumn{2}{|c|}{ SS } & \multicolumn{2}{|c|}{ Discoloration score } & \multicolumn{2}{|c|}{ Genotype ranking } & \multirow[b]{2}{*}{ Class $^{y}$} \\
\hline & SS & $a$ & SD & $b$ & $c$ & $d$ & \\
\hline $02 \mathrm{C} 14609$ & 1.0 & 1 & 0.0 & 1 & 2 & -2.7 & $\mathrm{R}$ \\
\hline $02 \mathrm{C} 14651$ & 1.0 & 1 & 0.0 & 1 & 2 & -2.7 & $\mathrm{R}$ \\
\hline $02 \mathrm{C} 14654$ & 1.0 & 1 & 0.0 & 1 & 2 & -2.7 & $\mathrm{R}$ \\
\hline $02 \mathrm{C} 14680$ & 1.0 & 1 & 0.0 & 1 & 2 & -2.7 & $\mathrm{R}$ \\
\hline $02 \mathrm{C} 14605$ & 1.0 & 1 & 0.7 & 2 & 3 & -2.6 & $\mathrm{R}$ \\
\hline $02 \mathrm{C} 14670$ & 1.0 & 1 & 0.7 & 2 & 3 & -2.6 & $\mathrm{R}$ \\
\hline $02 \mathrm{C} 14678$ & 1.0 & 1 & 0.8 & 3 & 4 & -2.4 & $\mathrm{R}$ \\
\hline $02 \mathrm{C} 14643$ & 1.0 & 1 & 1.0 & 4 & 5 & -2.3 & $\mathrm{R}$ \\
\hline $02 \mathrm{C} 14589$ & 1.0 & 1 & 1.1 & 5 & 6 & -2.2 & $\mathrm{R}$ \\
\hline $02 \mathrm{C} 14621$ & 1.0 & 1 & 1.1 & 5 & 6 & -2.2 & $\mathrm{R}$ \\
\hline $02 \mathrm{C} 14622$ & 1.0 & 1 & 1.2 & 6 & 7 & -2.0 & $\mathrm{R}$ \\
\hline $02 \mathrm{C} 14595$ & 1.0 & 1 & 1.4 & 7 & 8 & -1.9 & MR \\
\hline $02 \mathrm{C} 14649$ & 1.0 & 1 & 1.4 & 7 & 8 & -1.9 & MR \\
\hline $02 \mathrm{C} 14653$ & 1.3 & 2 & 1.9 & 8 & 10 & -1.6 & MR \\
\hline $02 \mathrm{C} 14607$ & 1.0 & 1 & 2.1 & 10 & 11 & -1.5 & MR \\
\hline $02 \mathrm{C} 14663$ & 1.0 & 1 & 2.1 & 10 & 11 & -1.5 & MR \\
\hline $02 \mathrm{C} 14588$ & 1.5 & 3 & 2.0 & 9 & 12 & -1.4 & MR \\
\hline $02 \mathrm{C} 14640$ & 1.5 & 3 & 2.0 & 9 & 12 & -1.4 & MR \\
\hline $02 \mathrm{C} 14661$ & 1.0 & 1 & 2.2 & 11 & 12 & -1.4 & MR \\
\hline $02 \mathrm{C} 14667$ & 1.5 & 3 & 2.3 & 12 & 15 & -1.0 & MR \\
\hline $02 \mathrm{C} 14683$ & 1.5 & 3 & 2.3 & 12 & 15 & -1.0 & MR \\
\hline $02 \mathrm{C} 14585$ & 1.5 & 3 & 2.4 & 13 & 16 & -0.9 & MR \\
\hline $02 \mathrm{C} 14619$ & 1.0 & 1 & 2.7 & 16 & 17 & -0.7 & MR \\
\hline $02 \mathrm{C} 14677$ & 1.5 & 3 & 2.6 & 14 & 17 & -0.7 & MR \\
\hline $02 \mathrm{C} 14624$ & 1.5 & 3 & 2.6 & 15 & 18 & -0.6 & MR \\
\hline $02 \mathrm{C} 14626$ & 1.5 & 3 & 2.9 & 18 & 21 & -0.2 & MR \\
\hline $02 \mathrm{C} 14655$ & 1.5 & 3 & 3.0 & 19 & 22 & -0.1 & MR \\
\hline Oba super 2 & 1.8 & 5 & 2.8 & 17 & 22 & -0.1 & MR \\
\hline $02 \mathrm{C} 14596$ & 1.5 & 3 & 3.1 & 20 & 23 & 0.1 & MS \\
\hline $02 \mathrm{C} 14629$ & 2.0 & 6 & 3.1 & 20 & 26 & 0.5 & MS \\
\hline $02 \mathrm{C} 14611$ & 1.8 & 5 & 3.3 & 22 & 27 & 0.6 & MS \\
\hline $02 \mathrm{C} 14628$ & 2.0 & 6 & 3.2 & 21 & 27 & 0.6 & MS \\
\hline $02 \mathrm{C} 14656$ & 1.6 & 4 & 3.5 & 24 & 28 & 0.7 & MS \\
\hline $02 \mathrm{C} 14613$ & 1.5 & 3 & 4.9 & 26 & 29 & 0.9 & MS \\
\hline $02 \mathrm{C} 14646$ & 2.0 & 6 & 3.4 & 23 & 29 & 0.9 & MS \\
\hline $02 \mathrm{C} 14645$ & 2.0 & 6 & 3.5 & 24 & 30 & 1.0 & MS \\
\hline $02 \mathrm{C} 14675$ & 2.0 & 6 & 3.5 & 24 & 30 & 1.0 & MS \\
\hline $9031-29$ & 2.1 & 7 & 3.4 & 23 & 30 & 1.0 & MS \\
\hline $02 \mathrm{C} 14616$ & 2.0 & 6 & 3.9 & 25 & 31 & 1.1 & MS \\
\hline $02 \mathrm{C} 14618$ & 2.0 & 6 & 3.9 & 25 & 31 & 1.1 & MS \\
\hline $02 \mathrm{C} 14606$ & 2.0 & 6 & 3.9 & 25 & 31 & 1.1 & MS \\
\hline $02 \mathrm{C} 14593$ & 2.5 & 9 & 4.9 & 26 & 35 & 1.7 & MS \\
\hline $02 \mathrm{C} 14582$ & 2.5 & 9 & 5.2 & 27 & 36 & 1.8 & MS \\
\hline $02 \mathrm{C} 14583$ & 2.5 & 9 & 5.7 & 28 & 37 & 1.9 & MS \\
\hline $02 \mathrm{C} 14627$ & 2.5 & 9 & 5.7 & 28 & 37 & 1.9 & MS \\
\hline Oba super 1 & 2.3 & 8 & 6.1 & 30 & 38 & 2.1 & $\mathrm{~S}$ \\
\hline AK9443DMRSR & 2.7 & 10 & 5.8 & 29 & 39 & 2.2 & $\mathrm{~S}$ \\
\hline $02 \mathrm{C} 14599$ & 2.5 & 9 & 6.4 & 32 & 41 & 2.5 & $\mathrm{~S}$ \\
\hline $02 \mathrm{C} 14679$ & 2.9 & 11 & 6.3 & 31 & 42 & 2.6 & $\mathrm{~S}$ \\
\hline $02 \mathrm{C} 14601$ & 2.9 & 11 & 6.4 & 32 & 43 & 2.7 & $\mathrm{~S}$ \\
\hline $02 \mathrm{C} 14617$ & 2.9 & 11 & 6.5 & 33 & 44 & 2.9 & HS \\
\hline $02 \mathrm{C} 14671$ & 3.0 & 12 & 6.9 & 34 & 46 & 3.1 & HS \\
\hline $02 \mathrm{C} 14603$ & 4.0 & 13 & 10.9 & 36 & 49 & 3.5 & HS \\
\hline $02 \mathrm{C} 14637$ & 4.0 & 14 & 9.6 & 35 & 49 & 3.5 & HS \\
\hline Mean & 1.7 & $\ldots$ & 3.1 & $\ldots$ & $22.5^{z}$ & $\ldots$ & $\ldots$ \\
\hline
\end{tabular}

${ }^{\mathrm{w}} \mathrm{SS}=$ severity score (mean of 2 years' data) based on a 1 to 5 scale and SD $=$ stalk discoloration (\%), mean of the 2 years' data; $a=$ inbred ranking using SS; $b=$ genotype ranking using SD; $c=$ rank-sum $(a+b)$ for each inbred; $d=$ deviation from the grand mean $(\mathrm{G})$ of the rank-sums $([d=(c-$ $\mathrm{G}) /$ standard deviation] $\times 2$ ).

${ }^{x}$ Oba super 1, Oba super 2, and 9031-29 are hybrids, while AK9443DMRSR is an open-pollinated cultivar.

${ }^{\text {y }} \mathrm{HR}=$ highly resistant, $\mathrm{R}=$ resistant, $\mathrm{MR}=$ moderately resistant, $\mathrm{MS}=$ moderately susceptible, $\mathrm{S}=$ susceptible, and HS = highly susceptible.

${ }^{\mathrm{z}}$ Grand mean of the rank-sums $(\mathrm{G})$. sessed using a severity scale $(5,14,22)$. Disease assessment using a severity rating scale is relatively easy to carry out compared with quantitative assessment such as tion. Stalk rot in maize is routinely asdirect assessment of stalk discoloration, different studies. Nonetheless, our results showed a good correlation between incidence of stalk discoloration and assessments based on a rating scale. Further, both methods produced consistent results across years, regardless of whether disease was initiated from artificial inoculation or natural infection. Certainly, the relatively simple rating scale is faster than the direct percentage estimation method. However, direct estimation of stalk discoloration, which gives more detailed evaluation of continuous variation, will be more effective in studying the genetic basis of resistance.

The modified rank-sum method (28) was employed to classify inbred lines into different categories of resistance or susceptibility. The suitability of this method in separating genotypes into specific resistance groups has been discussed elsewhere (28). The separation of genotypes based on their disease reaction relative to a known resistant check has been widely used (15). However, a major advantage of the ranksum method is that prior knowledge of the genetic structure of the test germplasm is not required. In this study, the four checks (Oba super 1, Oba super 2, 9031-29, and Ak9443DMRSR) were either susceptible or moderately susceptible to stalk rot. Inbred lines $02 \mathrm{C} 14654$ and $02 \mathrm{C} 14643$ that had consistently low levels of disease severity across locations and years were classified as either highly resistant or resistant to stalk rot. Other genotypes that were classified as resistant in both locations were 02C14609 and 02C14678. Thus, these four inbred lines could be valuable breeding stocks for use as parents of maize hybrids and synthetics with high levels of resistance to Fusarium stalk rot. Further, when genotypes were evaluated for resistance under artificial inoculation at Ibadan, inbred lines 02C14603 and 02C14624 were classified as resistant and moderately susceptible, respectively. These two inbred lines also have been identified to have low levels of Fusarium ear rot and fumonisin accumulation in grain, regardless of whether ear rot caused by $F$. verticillioides is initiated from artificial or natural infection (1). Thus, $02 \mathrm{C} 14603$ and $02 \mathrm{C} 14624$ could be useful in developing hybrids that combine resistance to both Fusarium ear rot and stalk rot caused by $F$. verticillioides.

This study identified some maize inbred lines with high levels of resistance to Fusarium stalk rot. These inbred lines can be used directly for the development of hybrids with good levels of resistance to stalk rot adapted to West and Central Africa and as sources of resistance genes in maize breeding programs. Because the inbred lines were derived from different crosses, they may have different resistance genes that are useful in breeding maize for resistance to Fusarium stalk rot. These inbred lines currently are being evaluated in Nige- which is labor intensive for large-scale evaluations. Direct estimation of disease severity is more accurate (11) than assessment based on a rating scale because visual assessments are often subjective, leading to variation between different users or 

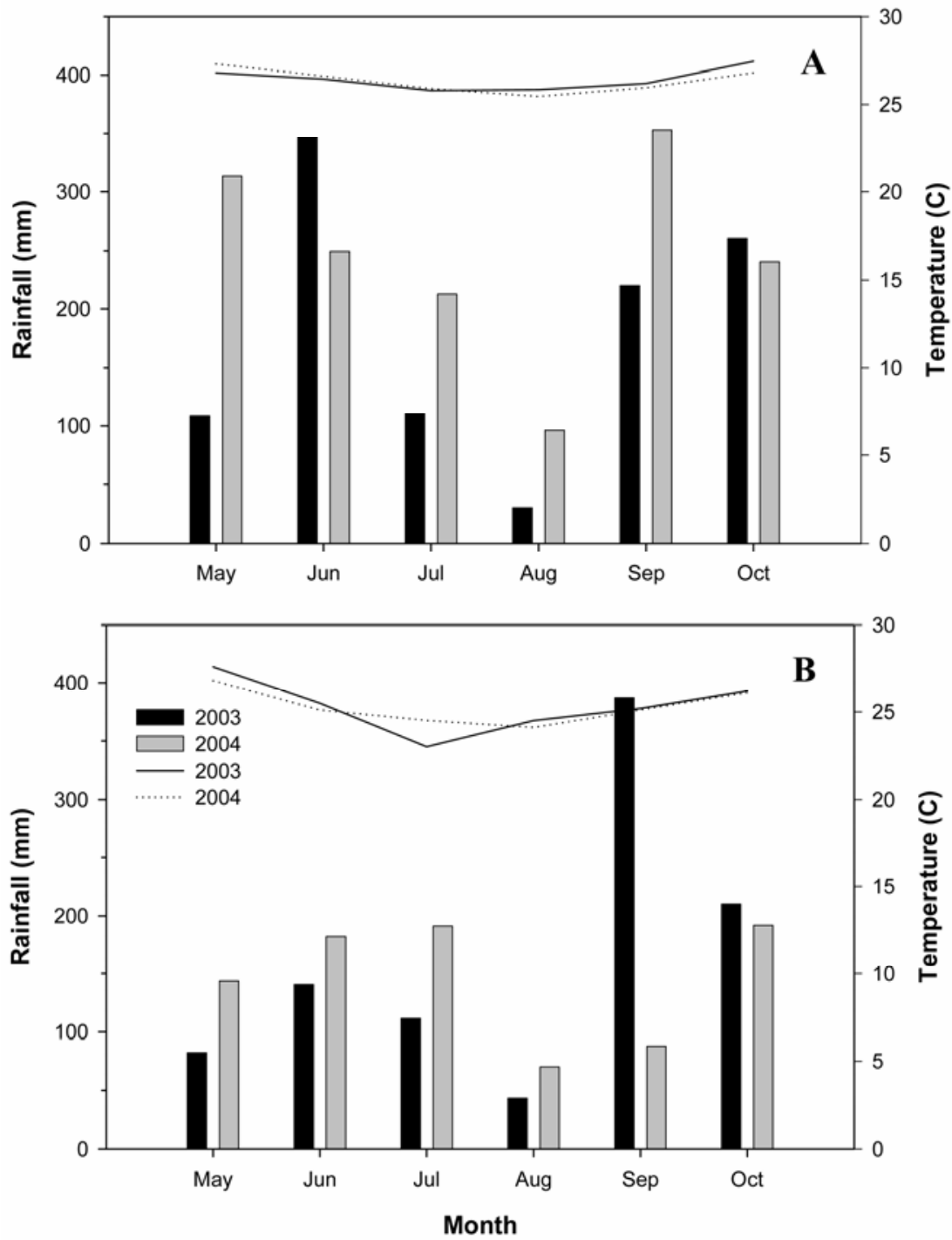

Fig. 5. Monthly rainfall (bars) and mean temperatures (lines) during the experimental period in 2003 and 2004 at International Institute of Tropical Agriculture research sites at A, Ikenne and B, Ibadan, Nigeria.

ria for resistance to Aspergillus ear rot and aflatoxin accumulation.

\section{ACKNOWLEDGMENTS}

We thank O. Ayinde for providing technical assistance.

\section{LITERATURE CITED}

1. Afolabi, C. G., Ojiambo, P. S., Ekpo, E. J. A., Menkir, A., and Bandyopadhyay, R. 2007. Evaluation of maize inbred lines for resistance to Fusarium ear rot and fumonisin accumulation in grain in tropical Africa. Plant Dis. 91:279-286.

2. Anonymous. 1985. Labor-saving technique to screen maize for resistance to stalk rots. Pages 82-83 in: IITA Annual Report and Research Highlights. Ibadan, Nigeria.

3. Ariyo, O. A., Dixon, A. G. O., and Atiri G. I. 2002. The relative resistance of cassava cultivars to African cassava mosaic disease (ACMD) as determined by two methods: ranksum and area under the disease progress curve. Arch. Phytopathol. Plant Prot. 35:23-30.

4. Bankole, S. A., Mabekoje, O. O., and Enikuomehin, O. A. 2003. Fusarium spp. and fumonisin $\mathrm{B}_{1}$ in stored maize from Ogun State, Nigeria. Trop. Sci. 43:76-79.

5. Bohra, B., Rathore, R. S., and Jain, M. L.
2001. Management of Fusarium stalk rot of maize caused by Fusarium moniliforme Sheldon. J. Mycol. Plant Pathol. 31:245-247.

6. Brown, R. L., Chen, Z.-Y., Menkir, A., Cleveland, T. E., Cardwell, K., Kling, J., and White, D. G. 2001. Resistance to aflatoxin accumulation in kernels of maize inbreds selected for ear rot resistance in West and Central Africa. J. Food Prot. 64:96-400.

7. Correll, J. C., Klittich, C. J. R., and Leslie, J. F. 1987. Nitrate non-utilizing mutants of Fusarium oxysporum and their use in vegetative compatibility tests. Phytopathology 77:16401646.

8. Dodd, J. L. 1980. The role of plant stresses in development of corn stalk rots. Plant Dis. 64:533-537.

9. Dodd, J. L. 1983. Corn stalk rot: Accounting for annual changes. Pages 71-79 in: Proc. 38th Annu. Corn Sorghum Res. Conf. Chicago.

10. Drepper, W. J., and Renfro, B. L. 1990. Comparison of methods for inoculation of ears and stalks of maize with Fusarium moniliforme. Plant Dis. 74:952-956.

11. Forbes, G. A., and Korva, J. T. 1994. The effect of using Horsfall Barratt scale on precision and accuracy of visual estimation of potato late blight severity in the field. Plant Pathol. 43:675-682.

12. Gatch, E. W., Hellmich, R. L., and Munkvold,
G. P. 2002. A comparison of maize stalk rot occurrence in Bt and non-Bt hybrids. Plant Dis. 86:1149-1155.

13. Gatch, E. W., and Munkvold, G. P. 2002. Fungal species composition in maize stalks in relation to European corn borer injury and transgenic insect protection. Plant Dis. 86:1156-1162.

14. Gilbertson, R. L., Brown, W. M., Jr., and Ruppel, E. G. 1985. Prevalence and virulence of Fusarium spp. associated with stalk rot of corn in Colorado. Plant Dis. 69:1065-1068.

15. Happstadius, A., Ljungberg, A., Kristiansson, B., and Dixelius, C. 2003. Identification of Brassica oleracea germplasm with improved resistance to Verticillium wilt. Plant Breed. 122:30-34.

16. Hooker, A. L. 1956. Association of resistance to several seedling, root, stalk, and ear diseases of corn. Phytopathology 46:379-384.

17. Hooker, A. L. 1973. New developments in the corn leaf and stalk disease picture. Pages 62-71 in: Proc. 28th Annu. Corn Sorghum Res. Conf. Chicago.

18. Hooker, A. L., and Draganič, M. 1980. Maize stalk rot ratings and predicting hybrid reaction from parental inbred reaction. Genetika 12:319-330.

19. Jardine, D. J., and Leslie, J. F. 1992. Aggressiveness of Gibberella fujikuroi (Fusarium moniliforme) isolates to grain sorghum under greenhouse conditions. Plant Dis. 76:897-900.

20. Koehler, B. 1960. Corn stalk rots in Illinois Univ. Ill. Bull. 658 .

21. Kommedahl, T., and Windels, C. E. 1981 Root-, stalk-, and ear-infecting Fusarium species on corn in the USA. Pages 94-104 in: Fusarium: Diseases, Biology, and Taxonomy P. E. Nelson, T. A. Toussoun and R. J. Cook, eds. Pennsylvania State University, University Park.

22. Ledenčan, T., Šimič, D., Brkić, I., Jambrović, A., and Zdunić, Z. 2003. Resistance of maize inbreds and their hybrids to Fusarium stalk rot. Czech J. Genet. Plant Breed. 39:15-20.

23. Lenné, J. M., and Thomas, D. 2006. Integrating crop-livestock research and development in Sub-Saharan Africa: option, imperative or impossible? Outlook Agric. 35:167-176.

24. Lin, C. S., and Poushinsky, G. 1983. A modified augmented design for an early stage of plant selection involving a large number of test lines without replication. Biometrics 39:553561.

25. Menkir, A., Brown, R. L., Bandyopadhyay, R., Chen, Z.-Y, and Cleveland, T. E. 2006. A USA-Africa collaborative strategy for identifying, characterizing, and developing maize germplasm with resistance to aflatoxin contamination. Mycopathologia 162:225-232.

26. Moormann, F. R., Lal, R., and Juo, A. S. R. 1975. Soils of IITA. International Institute of Tropical Agriculture, Ibadan, Nigeria.

27. Munkvold, G. P. 1996. Corn stalk rot in Iowa. Iowa State Univ. Ext. Publ. IPM 50.

28. Onyeka, T. J., Dixon, A. G. O., and Ekpo, E. J. A. 2005. Identification of levels of resistance to cassava root rot disease (Botryodiplodia theobromae) in African landraces and improved germplasm using in vitro inoculation method. Euphytica 145:281-288.

29. Reid, L. M., Nicol, R. W., Ouellet, T., Savard, M., Miller, J. D., Young, J. C., Stewart, D. W. and Schaafsma, A. W. 1999. Interaction of Fusarium graminearum and $F$. moniliforme in maize ears: Disease progress, fungal biomass, and mycotoxin accumulation. Phytopathology 89:1028-1037.

30. Romney, D. L. Thorneb, P., Lukuyuc, B., and Thornton, P. K. 2003. Maize as food and feed in intensive smallholder systems: management options for improved integration in mixed farming systems of east and southern Africa. Field Crops Res. 84:159-168. 
31. Russell, W. A. 1961. A comparison of five types of testers in evaluating the relationship of stalk rot resistance in corn inbred lines and stalk strength of the lines in hybrid combinations. Crop Sci. 1:93-97.

32. Schneider, R. W., and Pendery, W. E. 1983 Stalk rot of corn: mechanism of predisposition by an early season water stress. Phytopathology 73:863-871.

33. Smith, J. W., Naazie, A., Larbi, A., Agyemang, K., and Tarawali, S., 1997. Integrated crop- livestock systems in sub-Saharan Africa: an option or an imperative? Outlook Agric. 26:237-246.

34. Sobowale, A. A., Cardwell, K. F., Odebode, A. C., Bandyopadhyay, R., and Jonathan, S. G., 2007. Persistence of Trichoderma species within maize stem against Fusarium verticillioides. Arch. Phytopathol. Plant Prot. 40:215231.

35. White, D. G. 1999. Fungal stalk rots. Pages 38-44 in: Compendium of Corn Diseases. D.
G. White, ed. American Phytopathological Society Press, St. Paul, MN.

36. Wilke, A. L., Bronson, C. R., Tomas, A., and Munkvold, G. P. 2007. Seed transmission of Fusarium verticillioides in maize plants grown under three different temperature regimes. Plant Dis. 91:1109-1115.

37. Wolfinger, R. D., Federer, W. T., and CorderoBrana, O. 1997. Recovering information in augmented designs, using SAS PROC GLM and PROC MIXED. Agron. J. 89:856-859. 